\title{
Use of Technology by Teacher Trainees in Self-Financed Institutions
}

\author{
Umendra Singh* \\ Department of Teachers' Education, D.S. College, Aligarh, U.P. \\ Email Id: usds1979@gmail.com
}

\begin{abstract}
Education is very important for the progress of both the individual and the society. The unique contribution of education lies in making life progressive, cultural and civilized. Use of technology plays an important role for promoting relevant and interesting education. Educational technology implies the use of all modern media, methods and materials for maximizing the learning outcomes. All these methods, media and materials need be utilized in an integrated manner for ensuring optimization of learning. It would be very helpful for teachers in teaching. Now a days there are many institutions for training of elementary and secondary school teachers. But a large number of these institutions suffer from inadequate facilities - human, physical and academic to provide good professional education. Besides improving these facilities, it is necessary to provide modern media, materials and methods for accelerating the teaching-learning process.
\end{abstract}

Key Words: Technology, Teacher Trainees, Self-financed Institutions.

\section{PAPER/ARTICLE INFO RECEIVED ON: 11/04/2020 \\ ACCEPTED ON: 21/06/2020}

Reference to this paper should be made as follows:

Umendra Singh (2020), "Use of Technology by Teacher Trainees in Self-Financed Institutions", Int. J. of Trade and Commerce-IIARTC, Vol. 9, No. 1, pp. 159-163 


\section{INTRODUCTION}

As we know that education is not limited to the classroom teaching only. It has been broad-based and multi-dimensional. It is life-long, universal, free, and open. Education is learning, and learning is life. Learning, living, and working should go together. Education is not only life-long but also life-wide. Hence, there is no end to learning and no frontiers of learning. School is not the only institution of learning. It has ceased to monopolize the sources of knowledge. School is not the only education, and education is not the only schooling. The traditional curricula, methods, organization, and examination are found irrelevant to the modern age. Therefore, flexibility and multiplicity of media and materials are to be encouraged. Since the children of today are the citizens of tomorrow, they have to be provided with all kinds of facilities and techniques for practical as well as efficient learning.

In this context, education technology has been playing an essential role in promoting relevant and exciting education.

Educational technology implies the use of all modern media, methods, and materials for maximizing the learning outcomes. All the educational resources, men and materials, methods and techniques, means, and media need to be utilized in an integrated manner for ensuring optimization of learning. These include various methods of teaching audio-visual aids and materials for the effective and efficient teaching-learning process.

It is hoped that all these methods, media and materials which constitute 'Educational Technology,' would help teachers in teaching. So, educational technology has great importance for teachers.

\section{THE NEED FOR THE STUDY}

We belong to the high-tech society of the twenty-first century. The industrial age that most of us are familiar with is gradually fading away ushering in an era of information. An increase in information technology has negated the traditional notion of content mastery. The future learners will need to acquire critical thinking, decision making, and communication skills with an emphasis on the cognitive process of inquisitiveness and problem solving rather than knowledge acquisition and recall of facts. The teacher is now no longer considered as a transmitter of knowledge; instead, he is regarded as a catalyst and facilitator of learning. The dull stereotype pattern of 'Chalk, talk and teach' no longer holds any value. It is a need to switch over to dialogue, brain-storming, and more interaction between the teacher and learner from the mere verbal exposition. But are our future teachers well equipped with the methodologies of utilizing various sophisticated technologies to its maximum extent? Are they trained enough to bear the 'Future Shock'? The teacher is conceived as a change agent who can do wonders in transforming the society into an enlightened one, but is our teacher training institutions well equipped with necessary curricular and infrastructural facilities to prepare teachers for the future? These are some questions that raise the problem of the present study.

\section{OBJeCtIVES OF THE STUDY}

The present study aimed to achieve the following specific objectives:

- To identify the availability of technical equipment in self-financed teacher training institutions. 
- To identify whether the knowledge is given to the teacher trainees of using this equipment.

- To identify whether teacher trainees use this equipment in their teaching-practice.

- To identify the situations of future planning for using technical equipment by teacher trainees in their teaching.

- To identify whether the facility is provided for using this equipment to the trainees by selffinanced institutions.

\section{Delimitations}

The present study had been delimited on the following lines:

- The study was confined to the teacher trainees who were undergoing B.Ed. Course in selffinanced institutions.

- It was confined to only six self-financed institutions of M.J.P. Rohilkhand University, Bareilly, which are running B.Ed. Course.

\section{Methodology}

The methodology is a sound, systematic, and coherently organized treatment of the techniques of scientific research. The present study had been dealt with significantly by using the survey method.

\subsection{Population}

This study has a broader range and scope but keeping in view the limited time and economy. The researcher had restricted it to the affiliated self-financed institutions of teacher education at M.J.P. Rohilkhand University, Bareilly.

Teacher trainees of these institutions were the population of the present study. There were 20 selffinanced teacher training institutions in M.J.P. Rohilkhand University, Bareilly. Each institution had 100 teacher trainees except one. So the total population of the present study was about 2000 teacher trainees.

\subsection{Sample}

In the present study, a random sampling technique had been used. First of all, eight institutions had been selected from the total twenty institutions. After the selection of the institutions, the researcher decided the sample of 25 teachers trainees from each of these chosen institutions. So, the example was about 200 teacher trainees.

\subsection{Tools Used}

For finding out the solution to the problem, the use of technology by teacher trainees in selffinanced institutions, the researcher used a 'Check-List.' This check-list was constructed by the researcher under the supervision and guidance of his supervisor. Prof. N.N. Pandey, Dean, Faculty of Education \& Allied Sciences, M.J.P. Rohilkhand University, Bareilly.

\section{MAJOR FINDING}

a. The student-teachers above reported that technical equipment is available in self-financed teacher training institutions. Fifty percent of future teachers said that Radio, Tape-recorder, and Over Head Projector are available. Above forty percent reported that T.V. and slide 
Umendra Singh

projectors are available, whereas twenty-nine percent of pupil teachers said that VCR is also available. Eighty-five percent of prospective teachers said that a computer is available.

b. A significant part, which was eighty-five percent of the teacher trainees, said that the knowledge was provided for using this equipment.

c. Above forty percent of teacher, trainees reported that the knowledge of Radio, T.V., and Tape-Recorder was provided them by their teachers. Only twenty-seven percent said about VCR. Sixty-two percent said that the understanding of Over Head Projector and Computer was also offered them.

d. Only forty-two percent of future teachers said that this equipment was used by them in teaching practice, while fifty-eight percent of prospective teachers had denied.

e. Twelve percent of teacher trainees used radio, T.V., and slide-projector in teaching-practice, whereas twenty-nine percent of future teachers used Tape-recorder. Only eight percent said that they used VCR. Nearly twenty percent reported that they used Over Head Projector and Computer also. Only two percent of teacher trainees used other equipment.

f. Only eleven percent of future teachers had no future planning to use this equipment, while eighty-nine percent of student teachers wanted to use this equipment in the future.

g. In self-financed teacher training institutions, thirty-eight percent of teacher trainees had done future planning for Radio and Slide-Projector. Forty-seven percent of student teachers said that they would use tape Recorder and Over Head Project in the future. At the same time, T.V. will be used by thirty-two percent. Only twenty-six percent of student teachers did future planning for VCR. Sixty percent of prospective teachers reported that they would use computers, and only six percent will use other equipment.

h. Sixty-eight percent of teacher trainees in self-financed institutions accepted that the facility for using this equipment is available, whereas thirty-two percent had denied in this matter.

i. Forty-two percent of student teachers reported that this facility had been provided them by the permission of 'Head of the Department' while twenty-six percent of future teachers said that the consent of the Principal as necessary.

\section{EDUCATIONAL IMPLICATIONS}

The present study has the following educational implications to ascertain the problems of education:

a. The present study may be used by the National Council of Teacher Education (NCTE) to improve the quality of education.

b. This study may also be used by the State Government to do future planning in the field of teacher education.

c. This study is helpful to give affiliation to the institutions by the affiliated Universities.

d. Teacher Training Institutions may also use the present study to provide teacher trainees effective education. They can use this study to give them knowledge of technological equipment so that the teacher trainees may use this equipment in teaching practice and real teaching also.

e. Our future teachers may be well equipped with the methodologies of utilizing various sophisticated technologies to its maximum extent by this study. 
f. Technical equipment can do nothing in itself if the teacher trainees do not use this equipment. Therefore, the present study emphasizes the use of technology by teacher trainees in teaching so that they may be trained enough to bear the 'future shock.'

\section{SUGgESTIONS FOR FURTHER STUDIES}

Hindrances from time, economy, and available resources made the study limited to this extent. But there is an excellent scope of elaboration on the present topic in the course of further researches:

1. Due to a lack of time and resources, this study had been conducted only at M.J.P. Rohilkhand University, Bareilly. New researchers may take various universities of Uttar Pradesh.

2. This study is related to the use of technology by teacher trainees in self-financed institutions. In the next Study, Government aided institutions/ colleges may also be included.

3. This study is based on student teachers. In the next survey, teacher educators may also be included.

4. The present study was undertaken with a small number of samples. Therefore, the sample size may be enlarged to have specific generalizations.

5. A similar study may be conducted to verify and validate the results of the present investigation.

\section{REFERENCES}

[1]. Best, J.W. (1963): “Research in Education," Prentice-Hall, New Delhi.

[2]. Coombs, Philip H. (1985): "The World Crisis in Education: The View from the Eighties," New Delhi.

[3]. Kent, T.W. \& Mc. Nevgney, R.F. (1999): “Will Technology Change Education?” Corwin Press, California.

[4]. Office of Technology Assessment (1995): "Teachers and Technology: Making the Connection," Washington D.C., Government Printing Office.

[5]. Persichitte, K.A., Thorp, D.D. \& Caffarella, E.P. (1997): "The Use of Technology by Schools, Colleges, and Departments of Education," Washington D.C., American Association of Colleges for Teacher Education.

[6]. Ravishankar, S. (1982): "Evaluation of Management Training Programs in Public Enterprises with Special Reference to the use of Educational Technology," Ph.D. Education. 